\title{
Genetic Diversity of Mitochondrial DNA Cytochrome $b$ in Indonesian Native and Local Cattle Populations
}

\author{
Prihandini PW, Primasari A, Luthfi M, Efendy J, Pamungkas D \\ Beef Cattle Research Station Jl. Pahlawan, Grati - Pasuruan, East Java - Indonesia \\ E-mail: peniprihandini@pertanian.go.id
}

(received 21-04-2020; revised 15-05-2020; accepted 18-05-2020)

\begin{abstract}
ABSTRAK
Prihandini PW, Primasari A, Luthfi M, Efendy J, Pamungkas D. 2020. Keragaman genetik sitokrom $b$ mitokondria DNA pada populasi sapi asli dan lokal Indonesia. JITV 25(2):39-47. DOI: http://dx.doi.org/10.14334/jitv.v25i2.2496

Informasi tentang keragaman genetik ternak asli dan lokal di Indonesia sangat penting dalam pengembangan strategi pemuliaan dan konservasi. Tujuan penelitian ini untuk mengetahui keragaman dan hubungan genetik beberapa populasi sapi asli (Bali) dan lokal Indonesia [(Donggala, Madura, Sragen, Galekan, Rambon, dan Peranakan Ongole Grade x Bali (POBA)]. DNA genom diekstraksi dari sampel darah $(\mathrm{n}=75)$. Parsial sekuen mtDNA cyt $b(464 \mathrm{bp})$ diamplifikasi menggunakan teknik polymerase chain reaction (primer forward: L14735 dan primer reverse: H15149). Tiga puluh empat referensi sekuen dari Bos taurus, Bos indicus, dan Bos javanicus digunakan untuk analisis filogenetik. Hasil penelitian, sebanyak 55 situs polimorfik dan 13 haplotipe tersebar di semua populasi, namun, variasi mtDNA cyt $b$ tidak ditemukan di populasi Sapi Galekan yang dipelihara di Beef Cattle Research Station (BCRS) dan Sapi Rambon. Rataan haplotype diversity dan nucleotide diversity masing-masing adalah $0,515 \pm 0,070$ dan 0,0184 $\pm 0,0045$. Jarak genetik tertinggi $(0,092)$ dan terendah $(0,000)$ masing-masing yaitu antara populasi Sapi Bali dan Sapi Donggala dan antara Sapi Galekan (BCRS), Rambon, dan POBA. Berdasarkan analisis mtDNA network dan filogeni, terdapat dua maternal lineage (A dan B) pada populasi sapi Indonesia yang diteliti. Sebagian besar individu (69,33\%, tersebar dalam Haplotipe H8-H19) berada dalam lineage B, satu klaster dengan Bos javanicus. Disimpulkan bahwa populasi sapi asli dan lokal Indonesia memiliki keragaman genetik yang berbeda-beda; sebagian besar populasi sapi Indonesia memiliki maternal lineage dari Bos javanicus.
\end{abstract}

Kata Kunci: Sapi Indonesia, Sitokrom $b$, Keragaman Genetik, Filogeni Analisis

\begin{abstract}
Prihandini PW, Primasari A, Luthfi M, Efendy J, Pamungkas D. 2020. Genetic diversity of mitochondrial dna cytochrome $b$ in indonesian native and local cattle populations. JITV 25(2): 39-47. DOI: http://dx.doi.org/10.14334/jitv.v25i2.2496

Information on the genetic diversity of native and local cattle in Indonesia is vital for the development of breeding and conservation strategies. This study was aimed to assess the genetic diversity and phylogenetic relationship of the Indonesian native (Bali) and local [(Donggala, Madura, Sragen, Galekan, Rambon, dan Peranakan Ongole Grade x Bali (POBA)] cattle populations. Genomic DNA was extracted from blood samples $(\mathrm{n}=75)$. Partial sequences of mtDNA cyt $b$, $464 \mathrm{bp}$, were amplified using the polymerase chain reaction technique (forward primer: L14735 and reverse primer: H15149). Thirty-four reference sequences of Bos taurus, Bos indicus, and Bos javanicus were included in the phylogenetic analyses. A total of 55 polymorphic sites and 13 haplotypes were observed in the whole breeds. No variable sites of mtDNA cyt $b$ were observed in Galekan (kept in BCRS) and Rambon cattle. Overall haplotype diversity and nucleotide diversity were $0.515 \pm 0.070$ and 0.0184 \pm 0.0045 , respectively. The highest (0.092) and the lowest (0.000) genetic distances were between Bali and Donggala cattle populations and among Galekan (kept in BCRS), Rambon, and POBA cattle populations, respectively. Both mtDNA network and phylogenetic analyses revealed two major maternal lineages (A and B) of the studied population. Most of the sampled individuals $(69.33 \%$, present in haplotype $\mathrm{H} 8-\mathrm{H} 19)$ were linked to lineage B, which belonged to the same cluster with Bos javanicus. Overall, most of the Indonesian native and local cattle populations had a considerable genetic diversity and shared a common maternal origin with Bos javanicus.
\end{abstract}

Key Words: Indonesian Cattle, Cytochrome $b$, Genetic Diversity, Phylogenetic Analysis

\section{INTRODUCTION}

Cattle is one of the most important livestock commodities for Indonesian livestock farmers since they are mostly relying on cattle for their income. To date, several cattle, such as Sumba Ongole, Ongole
Grade, Jabres, Sumbawa, Pesisir, Aceh, and Madura have been identified as local cattle in Indonesia, while Bali cattle is the only native cattle breed in the country (Directorate of Livestock Breeding and Production 2020). Although some above-mentioned breeds have been well studied using microsatellite markers (Agung 
et al. 2019), there is still a lack of information focused on other cattle breeds, such as Rambon, Galekan, Donggala, and Sragen. As a part of animal genetic resources, it is well known that native cattle possess a considerable number of desirable traits, such as the ability to cope with hot weather environment, low quality of forage, resistance to the internal parasite, and infectious diseases. Therefore, they have a wide variation in morphological and physiological characteristics. Those variations are important in livestock populations to meet current production and future requirements in various environments and changing of objectives.

Recently, a lack of development of native cattle breeds and the introduction of exotic breeds has threatened the genetic diversity of native cattle breeds (Sutarno \& Setyawan 2016). Loss of genetic diversity within the breed and genetic erosion are major threats. Besides, genetic resources of locally adapted breeds with their unique characteristics have mostly been neglected. In this respect, it is now understood that it is important to establish conservation strategies to conserve the genetic diversity within and between breeds, especially prevent further losses of biodiversity. However, a lack of sufficient information regarding genetic resources of native cattle, including their current genetic diversity, rate of inbreeding, and genetic bloodmixture leads to the difficulty of making effective conservation strategies. Therefore, providing genetic information of native breeds is necessary for future conservation and breeding strategies.

Up to present, among many molecular markers available, mitochondrial DNA (mtDNA) has been widely employed to predict the genetic diversity and phylogenetic relationship in cattle (Sharma et al. 2015; Hartatik et al. 2019; Xia et al. 2019; Tarekegn et al. 2019; Yan et al. 2019). Unlike genomic DNA, mtDNA is characterized by a lack of recombination, maternal inheritance, and has a simple sequence organization (Harrison 1989). The mutation rate in mtDNA is much more frequent than in the nuclear gene, due to the absence of introns and its efficient repair mechanisms (Andalib et al. 2017). Cytochrome $b$ (cyt $b$ ) is an mtDNA gene, which is widely used for phylogenetic relationship determination in domestic animals, due to its sequence variability and high evolutionary rate (Othman et al. 2017; Tarekegn et al. 2018; Hartatik et al. 2019; Rahmatullaili et al. 2019). Furthermore, mtDNA cyt $b$ is a member of the protein-coding genes that has abundant phylogenetic information intraspecies and interspecies and higher variation ratio compared to other functional genes (Browers et al. 1994; Çiftci et al. 2013). Hence, mtDNA cyt $b$ is considered to be useful for the determination of genetic diversity and phylogenetic relationships.
Considering the above points, we, therefore, explored the mtDNA cyt $b$ to assess the genetic diversity and phylogenetic relationships of the Indonesian native and local cattle populations. This would provide basic data for future conservation and breeding strategies of Indonesian native cattle.

\section{MATERIALS AND METHODS}

\section{Blood sample collection and DNA extraction}

A total of 75 blood samples representing Indonesian native (Bali) and local (Donggala, Madura, Sragen, Galekan, Rambon, and Peranakan Ongole Grade x Bali crossbred) cattle populations were collected. Donggala (as DG; $\mathrm{n}=5$ ) cattle samples were collected from Donggala regency of Central Sulawesi province; Madura (as MD; $n=5$ ) cattle samples came from Pamekasan regency of East Java province, Sragen (as $\mathrm{SR} ; \mathrm{n}=9$ ) cattle samples were obtained from Sragen regency of Central Java province; Galekan cattle samples $(n=15)$ were collected from two different sites including the Beef Cattle Research Station (BCRS) (those kept in BCRS, as TL) and Unit Pelaksana Tugas Daerah (UPTD) of Trenggalek regency of East Java province (those kept in this region, as TU); Bali (as BL; $\mathrm{n}=5$ ) and Peranakan Ongole Grade x Bali (as POBA; $\mathrm{n}=24$ ) cattle samples were also collected from BCRS; and Rambon (as RM; $n=12$ ) cattle samples were obtained from Banyuwangi regency of East Java province. The genomic DNA was extracted from blood

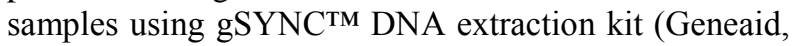
New Taipei City, Taiwan) and stored at $-20^{\circ} \mathrm{C}$ before further analysis.

\section{PCR amplification and sequencing}

A fragment of 464 bp from the partial mtDNA cyt $b$ sequences was amplified using polymerase chain reaction (PCR). The primers used were PR-L14735 (5'AAA AAC CAC CGT TGT TAT TCA ACT -3') and PF- H15149 (5' - GCC CCT CAG AAT GAT ATT TGT CCT CA -3') (Wolf et al. 1999). The PCR reaction was performed using Sensoquest (Germany) and made up of $2 \mu \mathrm{l}$ of template DNA (10-100 ng), $0.5 \mu \mathrm{l}$ of each primer $(0.25 \mu \mathrm{M}), 12.5 \mu \mathrm{l}$ PCR KIT $(2 \mathrm{x}$ My Taq HS Red Mix gSYNCTMPCR Kit-Bioline-London) and 9.5 $\mu \mathrm{lddH_{2 }}$ O to make a total volume of $25 \mu$ l. The thermal cycling included an initial denaturation at $94^{\circ} \mathrm{C}$ for 5 min, followed by 35 cycles of $94^{\circ} \mathrm{C}$ for $30 \mathrm{sec}, 58^{\circ} \mathrm{C}$ for $30 \mathrm{sec}$, and $72^{\circ} \mathrm{C}$ for $30 \mathrm{sec}$, with a final extension step at $72^{\circ} \mathrm{C}$ for $10 \mathrm{~min}$. The PCR products were sequenced using ABI 3730xl genetic analyzer (Applied Biosystems, Foster City, CA, USA). 


\section{Data analysis}

The mtDNA cyt $b$ gene sequences from 75 individuals of Indonesian native and local cattle were edited using BioEdit software (Hall 1999) and aligned using the ClustalW (Thompson et al. 1994). The mtDNA cyt $b$ diversity measures, such as the number of polymorphic sites (S), nucleotide differences $(\mathrm{K})$, haplotype diversity $(\mathrm{Hd})$, and nucleotide diversity $(\pi)$ were calculated using DnaSP version 6.12.01 software (Rozas et al. 2017). Genetic distances based on the Kimura two-parameter model algorithm were estimated using MEGA version 5.0 software (Kumar et al. 2016) and the resulted distance matrices were used to construct a neighbor-joining (NJ) tree with 1000 bootstrapping replicates using the same software of MEGA version 5.0 (Kumar et al. 2016). A median-joining network analysis was performed using NETWORK version 5.0.1.1 software (Bandelt et al. 1999). In this study, thirty-four sequences of Bos taurus (GenBank Accession No.: V00654; GQ129207; GQ129208; AY676860; AY676861; AY526085; AY885283; AF492351; EF693798; EU177834; EU177847; EU177852; EU177862; EU177867; EU747736; DQ124389; DQ186203; AY676866; DQ124413), Bos indicus (GenBank Accession No.: AF419237; AF492350; AF531473; AY126697; EU096517; EU096518; NC_005971; AY689190; EU096519), and Bos javanicus (GenBank Accession No.: D34636; D82889; AY689188; EF197952; DQ459558; DQ459559) from Asian, Europan, and American cattle, and Javan banteng were included in the phylogenetic network analysis.

\section{RESULTS AND DISCUSSION}

\section{Results}

\section{mtDNA sequence variation and genetic diversity}

The partial sequences of the mtDNA cyt $b$ gene, 464 bp in length, were successfully sequenced for 75 samples representing Indonesian native and local cattle breeds in Indonesia. As shown in Table 1, a total of 55 polymorphic sites and 13 haplotypes were observed in the whole breeds. Bali cattle had the highest number of polymorphic sites $(\mathrm{S}=31)$, while Galekan cattle kept on BCRS and Rambon cattle populations had no polymorphic sites observed $(\mathrm{S}=$ $0)$. The number of haplotypes ranged from 1 (TL and RM) to 5 (TU). The haplotype diversity varied from $0.000 \pm$ 0.000 (RM and TL) to $0.900 \pm 0.161$ (MD and BL), with an overall $\mathrm{Hd}$ value of $0.515 \pm 0.070$. The nucleotide diversity also varied from $0.000 \pm 0.000$ (RM and TL) to $0.0579 \pm 0.0131(\mathrm{MD})$. The overall nucleotide diversity among populations was $0.0184 \pm 0.0045$ (Table 1 ).

To elucidate the introgression of the exotic breeds in the studied populations, thirty-four mtDNA cyt $b$ gene sequences of Bos taurus, Bos indicus, and Bos javanicus available in GenBank database were included in the haplotype analysis. Of the nineteen haplotypes detected, only six haplotypes (H1, H4, H8, H10, H12, and H13) were shared by more than one population (Table 2). Haplotype H8, present in 52 sequences $(69.33 \%)$ out of 75 samples of the Indonesian native and local cattle populations and in 3 Javan banteng sequences was found to be the most frequent haplotype. Most of the remaining haplotypes, except $\mathrm{H} 1$ and $\mathrm{H} 4$, were present in four or fewer samples.

\section{Genetic distances and phylogenetic analysis}

Pairwise genetic distances among Indonesian native and local cattle populations estimated using the Kimura two-parameter model algorithm are shown in Table 3 . The highest genetic distance (0.092) was observed between Bali and Donggala cattle populations, while the lowest genetic distances (0.000) were observed among Galekan cattle kept on BCRS, Rambon, and POBA cattle populations. To determine the phylogenetic network of the Indonesian cattle populations, 19 haplotypes (Table 2) were used to construct the median-joining network (Figure 1). All the haplotypes were grouped into two main lineages (A and $\mathrm{B}$ ) and most of the Indonesian cattle haplotypes (H8-H19) were distributed in lineage B. Of the 75 individuals sampled, 68 samples $(90.67 \%)$ were present in lineage $B$, while only few samples $(n=7,9.33 \%)$ were linked to lineage A.

To confirm the MJ network results, a neighbor-joining (NJ) tree as indicated from the distance matrices was constructed (Figure 2). The results showed that Indonesian native and local cattle were grouped into two major lineages (A and B). Consistent with this result, when 34 reference sequences of the mtDNA gene from the GenBank database were included in the phylogenetic analysis for comparison, it showed that the Indonesian native and local cattle populations were clustered into two major lineages (A and B) (Figure 3). Lineage A was made up of all the cited Bos taurus and Bos indicus sequences and few sequences of Sragen, Madura, Galekan (at UPTD), and Donggala cattle populations. Interestingly, most sequences of the Indonesian cattle populations (TL, $\mathrm{BL}, \mathrm{RM}$, and POBA) were only clustered in lineage B, along with the cited Javan banteng sequences.

\section{Discussion}

\section{mtDNA sequence variation and genetic diversity}

Genetic diversity is basic source and a pivotal tool for future genetic improvement and selection programs in livestock populations. Considering this fact, partial sequences of mtDNA cyt $b$ (464 bp) from 75 individuals of Indonesian native and local cattle populations were 
Table 1. Genetic diversity of Indonesian native and local cattle populations based on mtDNA cyt $b$ gene partial sequences

\begin{tabular}{lcccccc}
\hline \hline Population & $\mathrm{N}$ & $\mathrm{S}$ & $\mathrm{H}$ & $\mathrm{K}$ & $\mathrm{Hd}$ & $\pi$ \\
\hline Donggala & 5 & 23 & 2 & 9.200 & $0.400 \pm 0.237$ & $0.0279 \pm 0.0165$ \\
Madura & 5 & 27 & 4 & 15.800 & $0.900 \pm 0.161$ & $0.0579 \pm 0.0131$ \\
Sragen & 9 & 26 & 3 & 6.056 & $0.639 \pm 0.126$ & $0.0184 \pm 0.0125$ \\
Galekan (BCRS) & 5 & 0 & 1 & 0.000 & $0.000 \pm 0.000$ & $0.0000 \pm 0.0000$ \\
Galekan (UPTD) & 10 & 29 & 5 & 5.956 & $0.667 \pm 0.163$ & $0.0181 \pm 0.0119$ \\
Bali & 5 & 31 & 4 & 13.800 & $0.900 \pm 0.161$ & $0.0437 \pm 0.0146$ \\
Rambon & 12 & 0 & 1 & 0.000 & $0.000 \pm 0.000$ & $0.0000 \pm 0.0000$ \\
POBA & 24 & 2 & 3 & 0.167 & $0.163 \pm 0.099$ & $0.0005 \pm 0.0003$ \\
Overall & 75 & 55 & 13 & 5.811 & $0.515 \pm 0.070$ & $0.0184 \pm 0.0045$ \\
\hline POBA= Peratan & Ongon
\end{tabular}

POBA $=$ Peranakan Ongole Grade $x$ Bali crossbreed, BCRS $=$ Beef Cattle Research Station

UPTD=Unit Pelaksana Teknis Daerah of Trenggalek regency

$\mathrm{N}=$ number of samples; $\mathrm{S}=$ segregating sites; $\mathrm{H}=$ number of haplotypes; $\mathrm{K}=$ nucleotide differences;

$\mathrm{Hd}=$ haplotype diversity; $\pi=$ nucleotide diversity

Table 2. Haplotypes shared among Indoesian native and local cattle populations and reference breeds from Bos taurus, Bos indicus and Bos javanicus

\begin{tabular}{lcc}
\hline \hline Haplotype & No. of samples & Population (No. of samples within population) \\
\hline H1 & 19 & Bos taurus (15), DG (4) \\
H2 & 1 & Bos taurus (1) \\
H3 & 1 & Bos taurus (1) \\
H4 & 10 & Bos indicus (7), MD (2), SR (1) \\
H5 & 1 & Bos indicus (1) \\
H6 & 1 & Bos indicus (1) \\
H7 & 2 & Bos taurus (2) \\
H8 & 55 & Bos javanicus (3), DG (1), MD (1), SR (5), TL (5), TU (6), RM (12), POBA (22) \\
H9 & 3 & Bos javanicus (3) \\
H10 & 2 & MD (1), TU (1) \\
H11 & 1 & MD (1) \\
H12 & 4 & SR (3), BL (1) \\
H13 & 3 & TU (1), BL (2) \\
H14 & 1 & TU (1) \\
H15 & 1 & TU (1) \\
H16 & 1 & BL (1) \\
H17 & 1 & BL (1) \\
H18 & 1 & POBA (1) \\
H19 & 1 & POBA (1) \\
\hline DG & 1 & SU
\end{tabular}

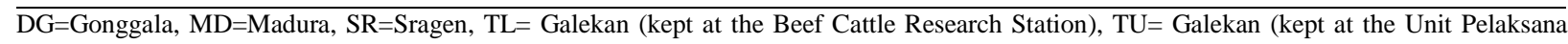
Teknis Daerah of Trenggalek regrecy), RM= Rambon, POBA= Peranakan Ongole Grade x Bali crossbreed, BL= Bali 
Table 3. Genetic distances among Indonesian native and local cattle populations based on mtDNA cyt $b$ gene partial sequences

\begin{tabular}{|c|c|c|c|c|c|c|c|c|}
\hline Population & Sragen & $\begin{array}{l}\text { Galekan } \\
\text { (BCRS) }\end{array}$ & $\begin{array}{l}\text { Galekan } \\
\text { (UPTD) }\end{array}$ & Bali & Rambon & POBA & Donggala & Madura \\
\hline Sragen & - & & & & & & & \\
\hline $\begin{array}{l}\text { Galekan } \\
\text { (BCRS) }\end{array}$ & 0.012 & - & & & & & & \\
\hline $\begin{array}{l}\text { Galekan } \\
\text { (UPTD) }\end{array}$ & 0.021 & 0.012 & - & & & & & \\
\hline Bali & 0.029 & 0.019 & 0.029 & - & & & & \\
\hline Rambon & 0.012 & 0.000 & 0.012 & 0.019 & - & & & \\
\hline POBA & 0.012 & 0.000 & 0.012 & 0.019 & 0.000 & - & & \\
\hline Donggala & 0.074 & 0.079 & 0.076 & 0.092 & 0.079 & 0.079 & - & \\
\hline Madura & 0.046 & 0.043 & 0.047 & 0.058 & 0.043 & 0.043 & 0.062 & - \\
\hline
\end{tabular}

POBA= Peranakan Ongole Grade $\times$ Bali crossbreed, BCRS= Beef Cattle Research Station, UPTD=Unit Pelaksana Teknis Daerah of Trenggalek regency

sequenced to determine their diversity. As a result, a wide range of genetic diversity, from low ( $\mathrm{Hd} \leq 0.163$ in TU; RM; and POBA) to high ( $\mathrm{Hd} \geq 0.900$ in $\mathrm{MD}$ and $\mathrm{BL}$ ), was observed. Compared to previous studies, the genetic diversities observed in this study $(\mathrm{S}=55 ; \mathrm{H}=13 ; \mathrm{Hd}=$ $0.515 ; \pi=0.0184)$ were much higher than those observed in Pasundan $(\mathrm{S}=1 ; \mathrm{H}=2 ; \mathrm{Hd}=0.1818 ; \pi=0.00045)$ and Pacitan $(\mathrm{S}=2 ; \mathrm{H}=3 ; \mathrm{Hd}=0.3778 ; \pi=0.00099)$ cattle of Indonesia (Hartatik et al. 2019), in Chikso cattle of Korea $(\mathrm{S}=15 ; \mathrm{H}=13 ; \mathrm{Hd}=0.4709 ; \pi=0.00055)(\mathrm{Kim}$ et al. 2013$)$, and in Ethiopian cattle ( $S=16 ; \pi=0.0010$ ) (Tarekegn et al. 2018) estimated using the same markers, but lower than those observed in Chinese cattle $(\mathrm{S}=78 ; \mathrm{H}=40 ; \mathrm{Hd}=$ 0.903 ) analyzed using mtDNA $16 \mathrm{~S}$ rRNA gene (Yan et al. 2019). A considerable genetic diversity observed in Indonesian native and local cattle populations indicated a lack of artificial selection pressure. Another reason for increased genetic diversity could be the introgression of several exotic breeds leading to genetic admixture, as proposed by Decker et al. (2014). This was reasonable because most of the Indonesian native and local cattle came from multiple maternal origins, such as Bos taurus, Bos indicus, and Bos javanicus (Pamungkas et al. 2012; Sutarno and Setyawan 2016). Although a moderate genetic diversity was observed in the whole breed, however, we did not observe any variable sites within partial sequences of mtDNA cyt $b$ gene in Galekan cattle kept at BCRS and Rambon cattle, while very few polymorphic sites $(S=2)$ were detected in POBA cattle population. These could be caused by the following reasons: a lack of heterozygous individuals present in these populations that might due to selection favoring homozygotes in multiple loci, and sampling bias, of which most of the animals sampled in each population could be collected from similar haplotype origin, and as a consequence, very few numbers of haplotypes were observed in the cyt $b$ region $(\mathrm{H}=1$ in TL, $\mathrm{H}=1$ in $\mathrm{RM}$, and $\mathrm{H}=3$ in POBA).

Contrarily, Bali and Madura cattle populations represented a high magnitude of mtDNA cyt $b$ gene diversity. The remaining cattle populations (DG, SR, and $\mathrm{TU}$ ), however, still represent a considerable genetic diversity. The high genetic diversity in Bali and Madura cattle, as indicated by the number of segregating sites $(\mathrm{S}=$ 31 in BL; $S=29$ in MD), might indicate a high mutation rate of the mtDNA cyt $b$ occurred in both populations. Similarly, Rahmatullaili et al. (2019) observed high nucleotide substitution in mtDNA cyt $b$ in Bali cattle leading to high genetic diversity within the population. Furthermore, a high mutation in mammalian mtDNA is due to replication errors, the poor fidelity of DNA polymerase, and the ROS-saturated environment present within mitochondrion ( $\mathrm{Li}$ et al. 2019). As indicated by the genetic diversity measures, Bali and Madura cattle populations had not only the highest nucleotide variation but also the highest haplotype and nucleotide diversity. Likewise, a high genetic diversity $(S=118 ; \pi=0.0250)$ was also found in Bali cattle based on mtDNA d-loop sequence analysis (Jakaria et al. 2019). Although a moderate level of genetic diversity was present in Bali cattle based on ETH10 microsatellite marker, the occurrence of inbreeding was observed (Margawati et al. 2018). A wide range of genetic diversities among the native cattle of Indonesia, especially in Bali and Madura cattle populations, however, could be valuable for future genetic improvement and selection of superior animals for economic traits. 


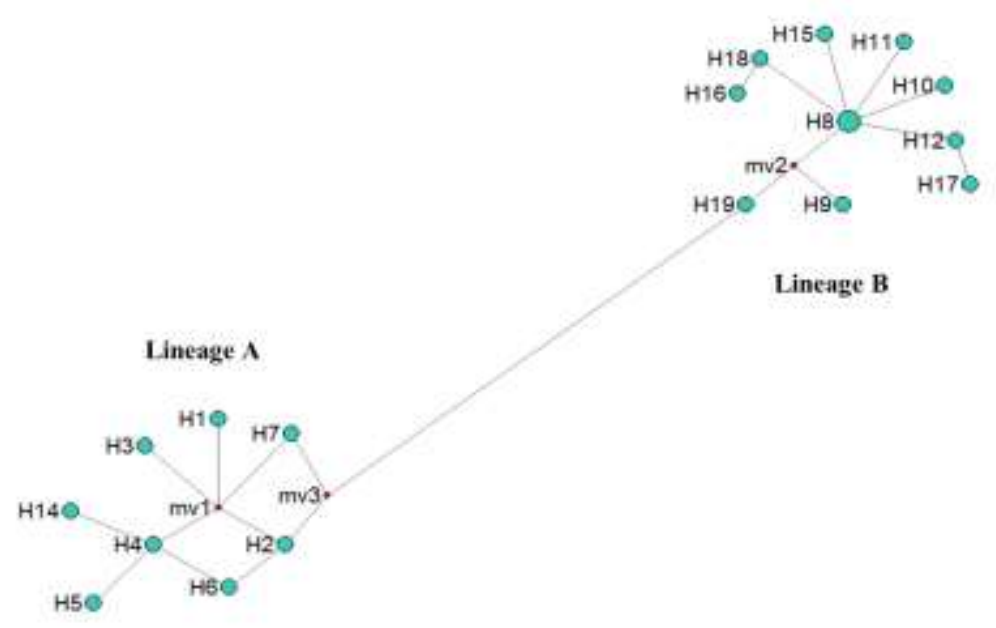

Figure 1. Median-joining network of 19 haplotypes based on cyt $b$ gene partial sequences (circle areas proportional to sample sizes)

\section{Phylogenetic tree}

A median-joining network based on the 19 haplotypes observed in this study was constructed to reveal the phylogenetic relationship among the cattle populations (Figure 1). All these haplotypes were grouped into two-major lineages (A and B). Of the 19 haplotypes observed, 11 haplotypes from the Indonesian native and local cattle populations were present in lineage B, along with Javan banteng haplotypes. Besides, Haplotype H8 represented the maternal origin of most of the Indonesian native and local cattle since most of the sampled animals (69.33\%) were linked to this haplotype. Only a few haplotypes from the studied populations were linked to lineage A, indicating that Bos taurus and Bos indicus maternal origins were little interfered with in our studied population. However, $75 \%$ of individuals of Donggala cattle were linked to this lineage and grouped in haplotype $\mathrm{H} 1$ along with 15 reference breeds of Bos taurus, indicating the introgression of Bos taurus in this population. Most of Bos taurus cattle in Indonesia came from Holstein Friesian (FH) breed (Sutarno and Setyawan 2016), but Limousin and Simmental cattle breeds have also been widely crossed with local breeds (Pamungkas et al. 2012). Therefore, a further comprehensive study should be addressed towards the genetic background of this breed. Since no works of literature are available regarding the genetic background of Donggala cattle so far, this study provides important information that could be valuable for future investigation of this animal genetic resource.

To reveal a more detailed summary regarding the genetic relationships among populations, two NJ trees (Figures 2 and 3) were constructed which supported the results of MJ network analysis. From two lineages observed, lineage A was more specific to Bos taurus and Bos indicus maternal origins, and very few samples of the studied populations (DG, MD, SR, and TU) were present in this lineage. Lineage $\mathrm{B}$ were distributed ubiquitously in the Indonesian cattle population (BL, RM, POBA, TL). This indicated a close genetic relationship among Indonesian cattle populations and higher levels of Bos javanicus ancestry in the studied breeds rather than Bos taurus and Bos indicus ancestries. Similarly, previous studies demonstrated a close genetic relationship between Indonesian cattle (Pasundan and Pacitan) since these breeds have a similar mtDNA maternal origin from Bos javanicus (Hartatik et al. 2019), and among Madura, Pasundan, and Pesisir cattle of Indonesia based on microsatellite analysis (Agung et al. 2019). Besides, Bos javanicus introgression has also been detected in Indonesian cattle, including in Madura and Galekan cattle tested using mitochondrial and Y-chromosomal analysis (Mohamad et al. 2012), in Aceh cattle detected using mtDNA d-loop sequences (Sari et al. 2016), in Bali, Java, and Limura (Limousin x Madura) cattle (Hartatik et al. 2015), and in Kebumen Ongole Grade cattle using mtDNA cyt $b$ (Hartatik et al. 2018). Furthermore, Bali and Madura cattle have a close genetic relationship based on Y-chromosomal microsatellite marker analysis (Winaya et al. 2015). Based on mtDNA and SRY gene analysis, a similar kind of banteng introgression in Bali cattle (124 out of 125 sampled individuals) had been reported, while the remaining one had zebu origin (Mohamad et al. 2012). Using genotypes from 43,043 autosomal single nucleotide polymorphism markers, Decker et al. (2014) also observed banteng introgression in Indonesian cattle breeds (Brebes, Madura, Pesisir, and Aceh) and Chinese Hainan and Luxi cattle. Zebu's introgression into Indonesian native cattle breeds (Aceh, Pesisir, Madura, Brebes) had been reported as well (Gao et al. 2017). 


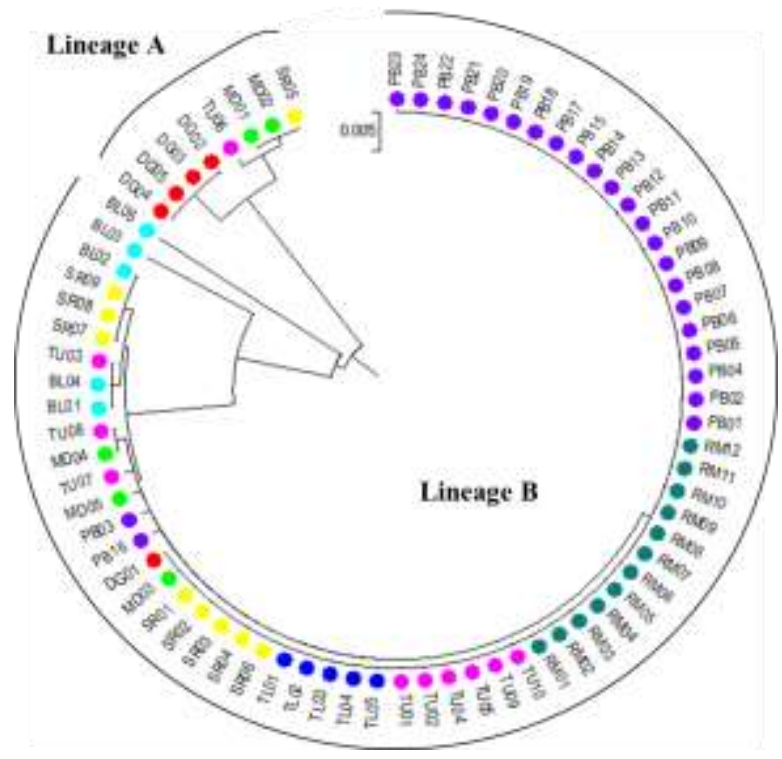

Figure 2. A neighbor-joining tree of Indonesian cattle populations tested based on cyt $b$ gene partial sequences

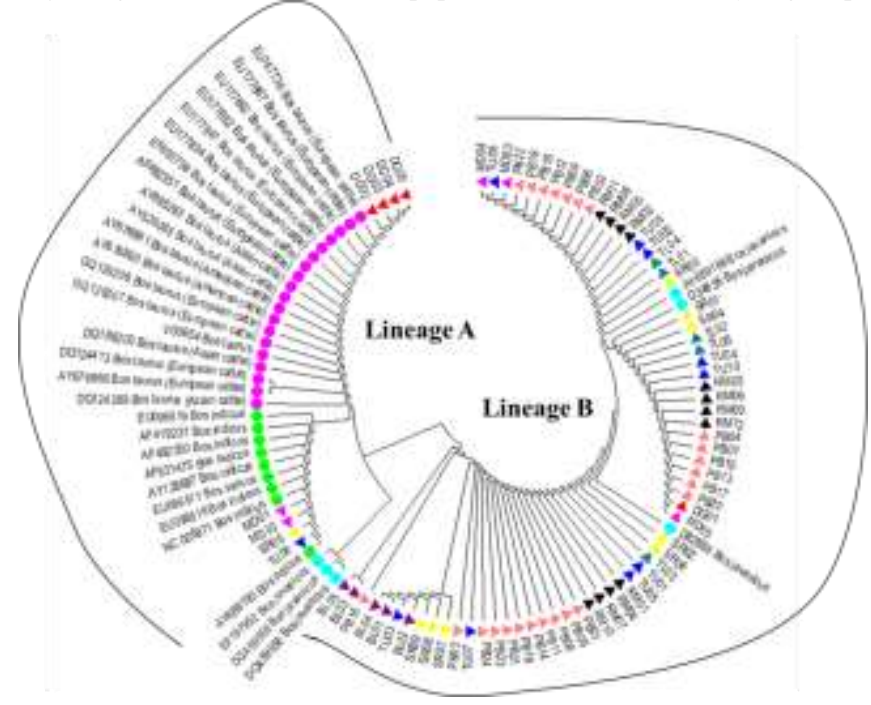

Figure 3. A neighbor-joining tree of 75 tested cattle and reference sequences (Bos taurus, Bos indicus and Bos javanicus)

Molecular phylogeny using mtDNA and SRY sequences clearly showed banteng-zebu type in Indonesian cattle, yak-zebu type in Nepal cattle, taurine type in ishima, Mongolian, Korean, and Chinese Yellow cattle, and zebu type in Sri Lanka cattle (Kikkawa et al. 2003). Asian domestic cattle like in Indonesia, however, may be hybrids and came from hybridization between multiple species from Bos taurus, Bos indicus, Bos javanicus, and Bos grunniens (Kikkawa et al. 2003; Jia et al. 2010).

Results of the present study and previous studies highlighted a considerable proportion of Javan banteng ancestry in most of the Indonesian cattle. However, since the introduction of exotic breeds from Bos taurus
(Holstein Friesian, Simental, and Limousin) as well Indian zebu cattle (Ongole breed) are continuously increasing, the blood proportion of the Indonesian cattle might change in future. Citing data from some previous studies, some Indonesian cattle breeds came from Bos indicus and Bos javanicus as well as their crosses. For instance, Rambon cattle are derived from Bos indicus $\mathrm{x}$ Bos javanicus; Madura cattle are a crossbreed between Balinese cattle (Bos javanicus) and zebu cattle (Bos indicus); Bali cattle are directly domesticated from wild banteng (Bos javanicus); and Aceh cattle are derived from the crossing between Ongole (Bos javanicus) and Bali (Bos javanicus) cattle (Mohamad et al. 2012; Sari et al. 2016; Sutarno et al. 2015; Sutarno \& Setyawan 
2016; Hartatik et al. 2019). In general, the results of the phylogenetic analysis obtained from this study were consistent with those of previous studies.

\section{CONCLUSION}

In this work, we demonstrated different diversities of mtDNA cyt $b$ gene within each population of Indonesian native and local cattle breeds, ranging from very low (TU; RM; and POBA) to high (MD and BL). The phylogenetic analysis revealed a quite close genetic relationship among the selected Indonesian cattle populations, which mostly belonged to Bos javanicus maternal origin. Finally, this study provided important data for future utilization of Indonesian cattle breeds and could be valuable to define breeding strategies.

\section{ACKNOWLEDGEMENT}

We are grateful to the Indonesian Agency of Agricultural Research and Development, Ministry of Agriculture for research fund in this work. The authors would like to thank the Farmers and Agricultural and Livestock Bureau of Sragen, Brebes, Donggala, Banyuwangi, Pamekasan and Trenggalek for helping in data collection. We also thank Dwi Nur Happy Hariyono and Yuli Arif Tribudi for their valuable input in completing the study and Tri Budi Dina, Heri, Mochammad Chanafi for their assistance during this research.

\section{REFERENCES}

Agung P, Saputra F, Zein MSA, Wulandari AS, Putra WPB, Said S, Jakaria J. 2019. Genetic diversity of Indonesian cattle breeds based on microsatellite markers. AsianAustralas J Anim Sci. 32: 467-476.

Andalib S, Divani AA, Michel TM, Høilund-Carlsen PF, Vafaee MS, Gjedde A. 2017. Pandora's Box: mitochondrial defects in ischaemic heart disease and stroke. Expert Rev Mol Med. 19:e5.

Bandelt HJ, Forster P, Rohl A. 1999. Median-joining networks for inferring intraspecific phylogenies. Mol Biol Evol. 16: 37-48.

Çiftci Y, Eroğlu O, Firidin Ş. 2013. Mitochondrial cytochrome $\mathrm{b}$ sequence variation in three Sturgeon species (A. stellatus Pallas, 1771, A. gueldenstaedtii Brandt, 1833, H. huso Linnaeus, 1758) from the Black Sea Coasts of Turkey. Turk J Fish Aquat Sci. 13: 291303.

Decker JE, Mckay SD, Rolf MM, Kim J, Molina AA, Sonstegard TS, et al. 2014. Worldwide patterns of ancestry, divergence, and admixture in domesticated cattle. PLoS Genetics. 10: e1004254.
Directorate of Livestock Breeding and Production. Jenis Rumpun Sapi. [cited 2020 April 6]. Available from:http://bibit.ditjenpkh.pertanian.go.id/jenisrumpun/sapi.

Gao Y, Gautier M, Ding X, Zhang H, Wang Y, Wang X, Faruque MDO, Li J, Ye S, Gou X, Han J, Lenstra JA, Zhang Y. 2017. Species composition and environmental adaptation of indigenous Chinese cattle. Sci Rep. 7: 16196.

Hall T. 1999. Bioedit: a biological sequence alignment editor and analysis program for windows 95/98/nt. Nucleic Acids Symp Ser. 41: 95-98.

Harrison RG. 1989. Animal mitochondrial DNA as a genetic marker in population and evolutionary biology. Trends Ecol Evol. 4: 6-11.

Hartatik T, Putra WBP, Volkandari SD, Sumadi. 2015. Polymorphism of mtDNA cytochrome $b$ gene of local cattle in Indonesia. J-SustaiN. 3: 21-24

Hartatik T, Maharani D, Sidadolog JHP, Fathoni A, Sumadi. 2018. Haplotype diversity of partial cytochrome $b$ gene in Kebumen Ongole Grade cattle. Trop Anim Sci J. 41: 8-14.

Hartatik T, Hariyono DNH, Adinata Y. 2019. Genetic diversity and phylogenetic analysis of two Indonesian local cattle breeds based on cytochrome $b$ gene sequences. Biodiversitas 20: 17-22.

Jia S, Zhou Y, Lei C, Yao R, Zhang Z, Fang X, Chen H. 2010. A new insight into cattle's maternal origin in six Asian countries. J Genet Genomics. 37: 173-80.

Jakaria J, Musyaddad T, Rahayu S, Muladno M, Sumantri C. 2019. Diversity of D-loop mitochondrial DNA (mtDNA) sequence in Bali and Sumba Ongole cattle breeds. J Indonesian Trop Anim Agric. 44: 335-345.

Kikkawa Y, Takada T, Sutopo, Nomura K, Namikawa T, Yonekawa H, Amano T. 2003. Phylogenies using mtDNA and SRY provide evidence for male-mediated introgression in Asian domestic cattle. Anim. Genet. 34: 96-101.

Kim JH, Byun MJ, Kim MJ, Suh SW, Ko YG, Lee CW, Jung KS, Kim ES, Yu DJ, Kim WH, Choi SB. 2013. mtDNA diversity and phylogenetic state of Korean cattle breed, Chikso. Asian-Australas J Anim Sci. 26: 163-170.

Kumar S, Stecher G, Tamura K. 2016. MEGA7: Molecular evolutionary genetic analysis version 7.0 for bigger datasets. Mol Biol Evol. 33: 1870-1874.

Li H, Slone J, Fei L, Huang T. 2019. Mitochondrial DNA variants and common diseases: a mathematical model for the diversity of age-related mtDNA mutations. Cells 8: 608 .

Margawati ET, Volkandari SD, Indriawati, Ridwan M. 2018. Genetic diversity and relationship among Bali cattle from several locations in Indonesia based on ETH10 microsatellite marker. JITV. 23:168-173. 
Mohamad K, Olsson M, Andersson G, Purwantara B, van Tol HTA, Rodriguez-Martinez H, Colenbrander B, Lenstra JA. 2011. The origin of Indonesian cattle and conservation genetics of the Bali cattle breed. Reprod Dom Anim 47: 18-20..

Othman OE, Abdel-Kader HAM, Alam SS, Abdel-Aziem SH. 2017. Cytochrome $b$ conservation between six camel breeds reared in Egypt. J Genet Eng Biotechnol. 15: 1-6.

Pamungkas D, Antari R, Mayberry DE, Poppi DP. 2012. A growth comparison of Ongole and European Cross cattle kept by smallholder farmers in Indonesia. Proceeding of the 15th Asian-Australasian Association of Animal Production (AAAP) Animal Science Congress, Bangkok, Thailand.

Rahmatullaili S, Fatmawati D, Nisa C, Winaya A, Chamisijatin L, Hindun I. 2019. Genetic diversity of Bali cattle: cytochrome $b$ sequence variation. IOP Conf Ser: Earth Environ Sci. 276: 012048.

Rozas J, Ferrer-Mata A, Sanchez-DelBarrio JC, Guirao-Rico S, Librado P, Ramos-Onsins SE, Sánchez-Gracia A. 2017. DnaSP 6: DNA sequence polymorphism analysis of large data sets. Mol Biol Evol. 34: 3299-3302.

Sari EM, Jianlin H, Noor RR, Sumantri C, Margawati ET. 2016. Phylogenetic analysis of Aceh cattle breed of Indonesia through mitochondrial D-loop region. J Genet Eng Biotechnol. 14: 227-231.

Sharma R, Kishore A, Mukesh M, Ahlawat S, Maitra A, Pandey AK, Tantia MS. 2015. Genetic diversity and relationship of Indian cattle inferred from microsatellite and mitochondrial DNA markers. BMC Genet. 30: 16:73.
Sutarno, Setyawan AD, Lymbery AJ. 2015. Genetic diversity of five Indonesian native cattle breeds at microsatellite loci. Asian J Anim Sci. 9: 57-64.

Sutarno, Setyawan AD. 2016. Review: The diversity of local cattle in Indonesia and the efforts to develop superior indigenous cattle breeds. Biodiversitas. 17: 273-295.

Tarekegn GM, Ji X, Bai X, Liu B, Zhang W, Birungi J, Djikeng A,Tesfaye K. 2018. Variations in mitochondrial cytochrome $b$ region among Ethiopian indigenous cattle populations assert Bos taurus maternal origin and historical dynamics. Asian-Australas J Anim Sci. 31: 1393-1400.

Thompson JD, Higgins DG, Gibson TJ. 1994. Clustal W: Improving the sensitivity of progressive multiple sequence alignment through sequence weighting, position-specific gap penalties and weight matrix choice. Nucleic Acids Res. 22: 4673-4680.

Winaya A, Muladno, Saefuddin A. 2015. Genetic diversity of Indonesian native cattle based on Y-chromosome microsatellite and its like-ladder DNA confirmation. J Anim Vet Adv. 14: 300-307.

Wolf C, Rentsch J, Hubner P. 1999. PCR-RFLP Analysis of Mitochondrial DNA: A reliable method for species identification. J Agric Food Chem. 47: 1350-1355.

Xia X, Qu K, Zhang G, Jia Y, Ma Z, Zhao X, Huang Y, Chen H, Huang B, Lei C. 2019. Comprehensive analysis of the mitochondrial DNA diversity in Chinese cattle. Anim Genet. 50: 70-73.

Yan L, She Y, Elzo MA, Zhang C, Fang X, Chen H. 2019. Exploring genetic diversity and phylogenic relationships of Chinese cattle using gene mtDNA 16S rRNA. Arch Anim Breed. 62: 325-333. 